\title{
Molecular identification of Pseudozyma aphidis (Henninger \& Windisch) Boekhout: first record from a Brazilian mangrove swamp
}

\author{
Marcela Castilho Boro ${ }^{1,2}$, Ana Lucia de Jesus ${ }^{1}$, José Ivanildo de Souza (in memoriam) ${ }^{1}$, Agostina Virginia \\ Marano $^{1}$ and Carmen Lidia Amorim Pires-Zottarelli ${ }^{1}$
}

Received: 11.01.2017; accepted: 17.10.2017

ABSTRACT - (Molecular identification of Pseudozyma aphidis (Henninger \& Windisch) Boekhout: first record from a Brazilian mangrove swamp). Pseudozyma aphidis (Henninger \& Windisch) Boekhout is an anamorph yeast-like basidiomycete commonly found as saprotroph in vegetable debris, such as leaves and flowers. However, there are also reports that this species is pathogenic in humans, usually occurring in patients with some type of immunosuppression, which predisposes to opportunistic infections. Specimens of $P$. aphidis were collected from water samples and Rhizophora mangle L. leaves at different salinities along the Perequê River, located in a mangrove swamp area at Parque Estadual da Ilha do Cardoso, Cananéia municipality, São Paulo State, Brazil. Aliquots of these samples were spread in Petri dishes. The samples baited with cataphylls of Allium cepa L. were incubated for seven days at $21{ }^{\circ} \mathrm{C}$. After incubation, the baits were observed under microscope and the specimens were isolated and purified. The identification of the specimens was made through the phylogenetic analysis of the ITS rDNA region. This is the first record of $P$. aphidis in São Paulo State.

Keywords: Atlantic rainforest, Basidiomycota, ITS, yeast-like fungi

RESUMO - (Identificação molecular de Pseudozyma aphidis (Henninger \& Windisch) Boekhout: primeira citação em um manguezal brasileiro). Pseudozyma aphidis (Henninger \& Windisch) Boekhout é um basidiomiceto anamórfico leveduriforme comumente encontrado como sapróbio em detritos vegetais, como folhas e flores. No entanto, há relatos de que esta espécie é patogênica em seres humanos, geralmente ocorrendo em pacientes com algum tipo de imunossupressão que predispõe infecções oportunistas. Espécimes de P. aphidis foram coletados a partir de amostras de água e de folhas de Rhizophora mangle L. em diferentes salinidades ao longo do rio Perequê, localizado em um manguezal no Parque Estadual da Ilha do Cardoso, município de Cananéia, Estado de São Paulo, Brasil. No laboratório, alíquotas destas amostras foram colocadas separadamente em placas de Petri, iscadas com catafilos de Allium cepa L. e incubadas por sete dias a $21^{\circ} \mathrm{C}$. Após incubação, as iscas foram observadas ao microscópio e os espécimes foram isolados e purificados. A identificação dos espécimes foi realizada através da análise filogenética da região ITS rDNA, sendo este o primeiro registro de $P$. aphidis no Estado de São Paulo.

Palavras-chave: Basidiomycota, fungo leveduriforme, ITS, Mata Atlântica

\section{Introduction}

Pseudozyma Bandoni emend. Boekhout pro tempore comprises approximately 25 distinct anamorphic yeast species from the Ustilaginaceae, Basidiomycota (Index Fungorum 2016). Although a reliable connection with their teleomorph stages has not been established for many of these species (Boekhout 2011), recent studies have proposed to transfer anamorphic yeast species to their corresponding teleomorphic genera based on strongly supported phylogenetic affinities (Piatek et al. 2015, Wang et al. 2015). From these studies, many species of the genus Pseudozyma have been transferred to the genus Moesziomyces, as is the case of Pseudozyma aphidis (= Moesziomyces aphidis) and the use of the "pro tempore" was suggested by the authors to indicate that in Pseudozyma species names are temporarily remained. The results of these studies allowed the proposition of 16 new combinations for Pseudozyma (Index Fungorum 2016), however, the taxonomic status of five species still remains to be determined because of their uncertain phylogenetic positions (Bandoni 1985, Boekhout 1995, Sugita et al. 2003, Wang et al. 2006, Liou et al. 2009).

1. Instituto de Botânica, Núcleo de Pesquisa em Micologia, Av. Miguel Stéfano 3687, 04301-012 São Paulo, SP, Brazil

2. Corresponding Author: marcelaboro@gmail.com 
This genus has been isolated from different types of materials such as leaves (Golubev et al. 2007, Chamnanpa et al. 2013), flowers (Wei et al. 2005, Liou et al. 2009), blood samples (Sugita et al. 2003, Mekha et al. 2014) and even associated with coral reefs and insects (Henninger \& Windisch 1975, StatzellTallman et al. 2010, Oliveira et al. 2014). Pseudozyma aphidis (Henninger \& Windisch) Boekhout was firstly described as Sterigmatomyces aphidis Henninger \& Windisch in Germany and isolated from Aphididae secretions on leaves of Solanum pseudocapsieum (Henninger \& Windisch 1975). This species is commonly found as a saprotroph on leaves and flowers (Han et al. 2015, Limtong \& Kaewwichian 2015, Nasanit et al. 2015, Tantrungkij et al. 2015), although it is not pathogenic to plants. However, there are reports of this species as pathogenic in humans (Prakash et al. 2014, Herb et al. 2015, Joo et al. 2015, Orecchini et al. 2015), usually occurring in patients with some type of immunosuppression that predisposes opportunistic infections.

In Latin America, the first report of $P$. aphidis was in Brazil when Costa (2006) reported the presence of this species, through molecular identification of the region D1/D2 of 26S rDNA, in semi-arid soil from Mucugê municipality, Bahia State. Tristão et al. (2012) reported an association of $P$. aphidis with pineapple fruits sampled from the Central Region of Tocantins State. As a human pathogen, the first case was reported from a public pediatric oncology center in Recife, Pernambuco State, causing pulmonary infection in a patient with Burkitt lymphoma (Parahym et al. 2013).

The occurrence and activity of yeasts in marine waters have been observed worldwide since first reported by Fischer \& Brebeck (1894) and is well established due to their role in the decomposition of organic substrates, nutrient cycling, hydrocarbon biodegradation, and as pathogenic for a variety of marine organisms (Vogel et al. 2007, Kutty \& Philip 2008). Species of Pseudozyma, including P. aphidis, have commonly been reported in marine and mangrove environments (Gadanho et al. 2003, Statzell-Tallman et al. 2010, Fell et al. 2011).

Several papers have also shown the potential of this species for inducing systemic resistance and as a biocontrol agent against plant pathogens of different crops (Tristão et al. 2012, Buxdorf et al. 2013a, b, Gafni et al. 2015). They are also reported as a potential source of squalene (Chang et al. 2008), lipase (Dimitrijevic et al. 2011) and biosurfactant mannosylerythritol lipids (Morita et al. 2007, Fan et al. 2014, Lorenz et al. 2014, Gunther et al. 2015).

Molecular methods are useful tools for the accurate positioning of yeasts within the Kingdom Fungi, being the classic methods of limited value due to the low morphological variation between species and the existence of a significant yet undescribed diversity (Hoog et al. 1998). The use of nucleotide sequences of internal transcribed spacer (ITS) of the rDNA region is considered the best tool for rapid and accurate identification of yeast isolates (White et al. 1990).

During a survey at the Parque Estadual da Ilha do Cardoso (PEIC), we identified four isolates of $P$. aphidis based on the phylogenetic analysis of the ITS rDNA region. Thus, the aim of this study is to present the phylogeny of the genus with the inclusion of specimens collected in this mangrove area of Brazilian Atlantic Rainforest.

\section{Material and methods}

The Pseudozyma specimens used in this study were isolated from water samples and Rhizophora mangle L. leaves collected (in sterile plastic bottle) in the months of August and November 2012 at different salinities (1.5 to $3 \%$ ) along the Perequê River. The study area is located in a mangrove swamp from Parque Estadual da Ilha do Cardoso (PEIC), $25^{\circ} 03^{\prime} 05^{\prime \prime}-25^{\circ} 18^{\prime} 18^{\prime \prime} \mathrm{S} ; 47^{\circ} 53^{\prime} 48^{\prime \prime}-48^{\circ} 05^{\prime} 42^{\prime \prime} \mathrm{W}$, situated in Cananéia municipality, São Paulo State, Brazil. This island is a preserved fragment of Atlantic Rainforest that contains different types of vegetation, including tropical forest, "restinga", dunes and mangrove swamps, with several water bodies like waterfalls, streams and rivers (Barros et al. 1991). During the sampling, the surface water temperature of the estuary was lower in August, about $20^{\circ} \mathrm{C}$ and higher in November, about $27^{\circ} \mathrm{C}$.

Aliquots $(30 \mathrm{~mL})$ of water samples and disks (1 $\mathrm{cm}$ diameter) of $R$. mangle leaves (washed in sterilized seawater) together with $30 \mathrm{~mL}$ of a dilution of $50 \%$ reverse osmosis and 50\% seawater, were placed separately in Petri dishes. These samples were baited with cataphylls of Allium cepa L. (Sparrow 1960, Milanez 1989) and incubated for seven days at $21{ }^{\circ} \mathrm{C}$. After incubation, the baits were observed under microscope and the specimens were isolated and purified onto PYGs culture medium (Fuller \& Jaworski 1987) prepared with a dilution of $50 \%$ sterile seawater, penicillin $\mathrm{G} 0.4 \mathrm{~g} \mathrm{~L}^{-1}$ and streptomycin sulphate $0.4 \mathrm{~g} \mathrm{~L}^{-1}$. 
Table 1. Taxa, strain numbers and GenBank accession numbers of the species considered in this study.

\begin{tabular}{|c|c|c|}
\hline Taxa & Strain number & GenBank accession number \\
\hline Cintractia axicola & HUV17460 & AY344967 \\
\hline Trichocintractia utriculicola & MP 2075 & DQ875354 \\
\hline Pseudozyma abaconensis & CBS8380 & FJ008053 \\
\hline Pseudozyma alboarmeniaca & DMST17135 & AB117961 \\
\hline Pseudozyma antarctica & JCM10317 & AB089358 \\
\hline Pseudozyma antarctica & JCM3941 & JN942669 \\
\hline Pseudozyma aphidis* & CCIBt 4253 & KY288985 \\
\hline Pseudozyma aphidis* & CCIBt 4254 & KY288982 \\
\hline Pseudozyma aphidis* & CCIBt 4255 & KY288981 \\
\hline Pseudozyma aphidis* & CCIBt 4256 & KY288984 \\
\hline Pseudozyma aphidis & CBS51783 & AF294699 \\
\hline Pseudozyma aphidis & IMUFRJ51941 & FN424100 \\
\hline Pseudozyma aphidis & JCM10318 & AB089362 \\
\hline Pseudozyma aphidis & LH59 & HQ832804 \\
\hline Pseudozyma brasiliensis & GHG001 & KF737866 \\
\hline Pseudozyma churashimaensis & OK96 & AB548947 \\
\hline Pseudozyma churashimaensis & OK99 & AB548950 \\
\hline Pseudozyma crassa & DMST17136 & $\mathrm{AB} 117062$ \\
\hline Pseudozyma flocculosa & JCM10321 & AB089364 \\
\hline Pseudozyma fusiformata & JCM3931 & AB089366 \\
\hline Pseudozyma fusiformata & AP6 & FJ919774 \\
\hline Pseudozyma graminicola & LI20 & AB180728 \\
\hline Pseudozyma hubeiensis & AS2.2493 & DQ008954 \\
\hline Pseudozyma hubeiensis & LH146 & HQ832814 \\
\hline Pseudozyma jejuensis & CBS10454 & EF079966 \\
\hline Pseudozyma jejuensis & IMUFRJ52021 & FN428892 \\
\hline Pseudozyma parantarctica & JCM11752 & NR130693 \\
\hline Pseudozyma parantarctica & M9932 & AB089356 \\
\hline Pseudozyma prolifica & JCM10319 & AB089368 \\
\hline Pseudozyma prolifica & CBS31987 & AF294700 \\
\hline Pseudozyma pruni & BCRC34227 & EU379942 \\
\hline Pseudozyma rugulosa & M12 & FJ464594 \\
\hline Pseudozyma rugulosa & JCM10323 & AB089370 \\
\hline Pseudozyma rugulosa & CBS17088 & AF294697 \\
\hline Pseudozyma shanxiensis & AS2.2523 & DQ008956 \\
\hline Pseudozyma shanxiensis & SN37 & FJ515182 \\
\hline Pseudozyma siamensis & DMST17137 & AB117963 \\
\hline Pseudozyma thailandica & M9933 & AB089354 \\
\hline Pseudozyma tsukubaensis & JCM10324 & AB089372 \\
\hline Pseudozyma tsukubaensis & KM160 & AB855769 \\
\hline Pseudozyma vetiver & DMKU-LV99 & AB809652 \\
\hline Pseudozyma vetiver & DMKU-LV90 & AB809651 \\
\hline
\end{tabular}

* Taxa, strain numbers and GenBank accession numbers of the isolates of Pseudozyma aphidis sequenced in this study. 


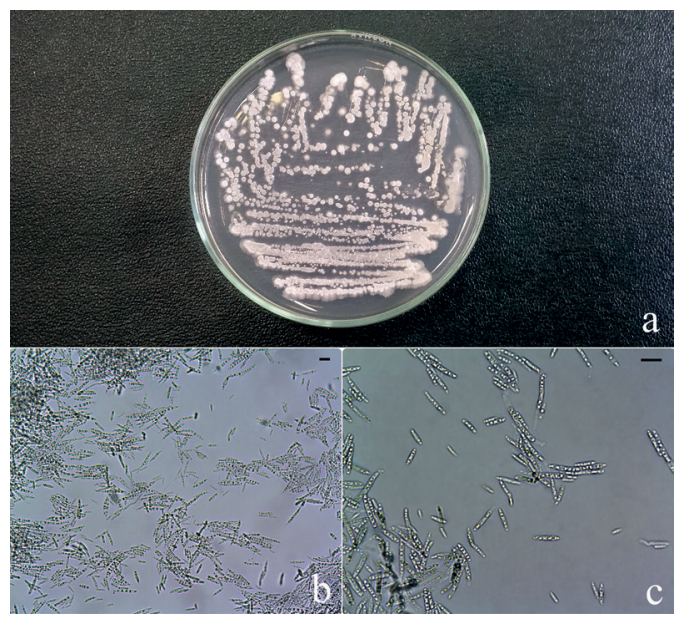

Figure 1. a-c. Pseudozyma aphidis. a. One-week old culture onto PYGs culture medium. b-c. Yeast-like fungi cells obtained from colonies growing onto PYGs culture medium. Bars $=10 \mu \mathrm{m}$.
The specimens were preserved by the Castellani's method $(50 \%$ sterile reverse osmosis water and $50 \%$ sterile seawater) and posteriorly deposited at the CCIBt culture collection (Coleção de Culturas de Algas, Cianobactérias e Fungos do Instituto de Botânica, São Paulo, SP, Brazil).

Biomass for DNA extraction was obtained by cultivating each isolate onto PYGs culture medium, prepared with a dilution of $50 \%$ sterile seawater, penicillin G $0.4 \mathrm{~g} \mathrm{~L}^{-1}$ and streptomycin sulphate $0.4 \mathrm{~g} \mathrm{~L}^{-1}$, for seven days at $21^{\circ} \mathrm{C}$. After incubation, the cells were harvested using a platinum loop. The DNA extraction followed the protocol described in the PureLink Genomic DNA kit (Invitrogen ${ }^{\circledR}$ ). The ITS1-5.8S-ITS2 region was amplified using the primers UN-up18S42 and UN-lo28S22 (Robideau et al. 2011). PCR amplification was performed with

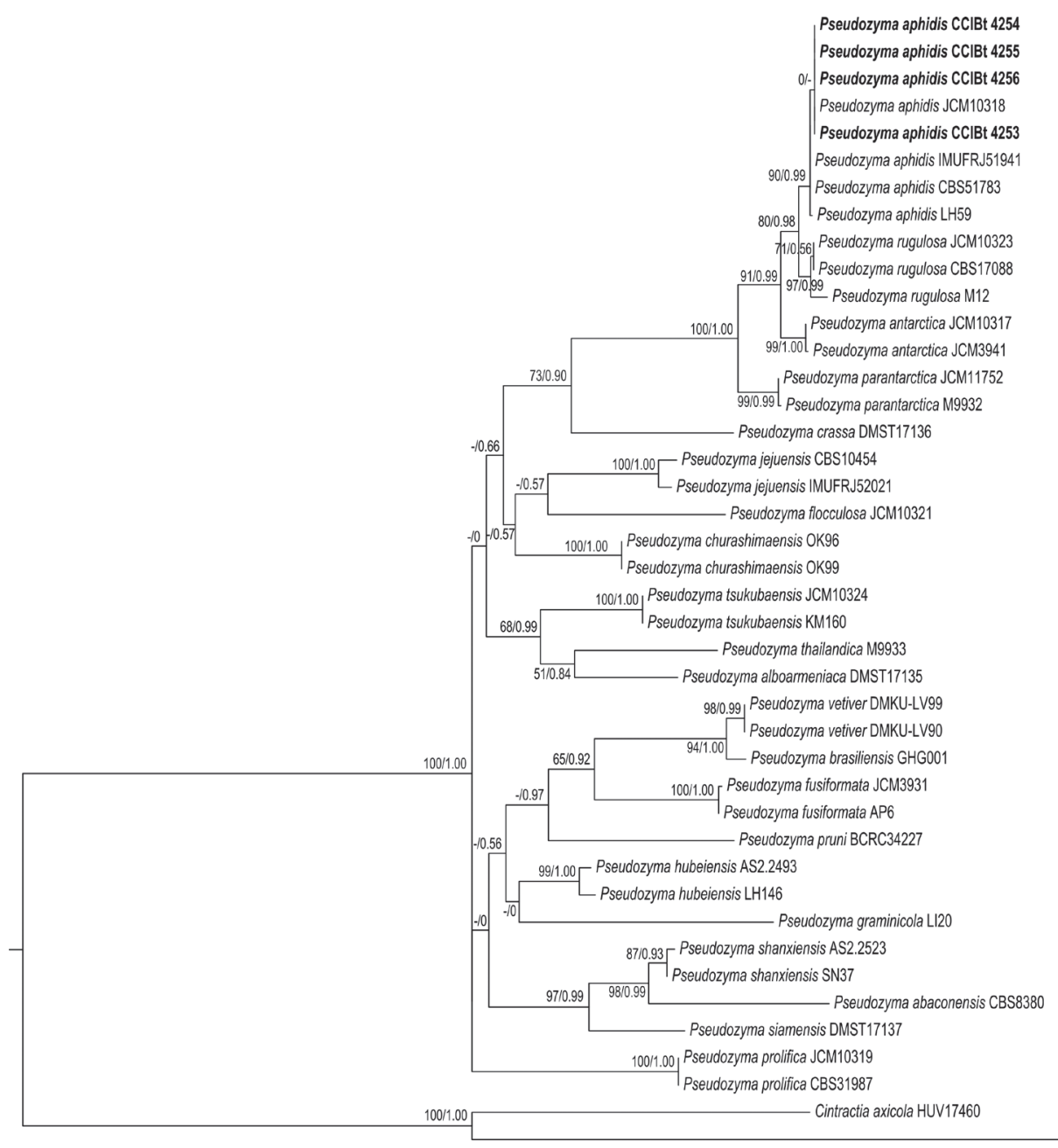

Figure 2. Maximum likelihood tree of internal transcribed spacer (ITS) rDNA sequences of Pseudozyma spp. Maximum likelihood bootstrap support and posterior probability values large than 50\% are indicated numerically, those under 50\% are marked with (-). Those clades that were not present in the Bayesian trees are marked as $(0)$. The scale bar represent the average number of substitutions per site 
the PCR SuperMix kit $\left(\right.$ Invitrogen $\left.^{\circledR}\right)$ for a final volume of $25 \mu 1$ in a 1000 Touch $^{\mathrm{TM}}$ Thermal Cycler Bio-Rad following the conditions described by Marano et al. (2014). Amplicons were purified with AxyPrep PCR Clean-up kit $\left(\right.$ Axygen $\left.^{\circledR}\right)$. Sequencing was performed using the same PCR primers in an ABI 3730 DNA Analyser (Life Technologies ${ }^{\mathrm{TM}}$ ). Assembly of contigs and correction of ambiguous bases were manually edited using Sequencher ${ }^{\mathrm{TM}}$ version 4.1.4.

The ITS sequences obtained were compared against BLASTn (Basic Local Alignment Search Tool). For phylogenetic reconstruction, we used ITS rDNA sequences of our isolates and of the other isolates of Pseudozyma available at GenBank (table 1). We analysed 42 sequences from 23 species, using Cintractia axicola (Berk.) Cornu and Trichocintractia utriculicola (Henn.) M. Piepenbr. as outgroups. Sequences were aligned using MAFFT version 7 (Kazutaka \& Daron 2013), the ambiguously aligned characters were removed manually using Geneious version 8 (Kearse et al. 2012) and the alignment was deposited in the Treebase (Boettinger \& Lang 2011). The best fitting model of evolution was selected using the Akaike Information Criterion in jModeltest version 0.1.1 (Posada 2008). The Maximum Likelihood (ML) phylogenies were reconstructed with PhyML version 3.1 (Guindon \& Gascuel 2003) using the TPm2uf $+\mathrm{G}$ substitution model, branch swapping by best of NNI and SPR, and support for nodes obtained by 1,000 bootstrap pseudo-replicates. Bayesian inferences (BI) were generated using MrBayes version 3.2.1 (Ronquist \& Huelsenbeck 2003) with Markov Chain Monte Carlo (MCMC) methodology to calculate posterior probabilities of the phylogenetic trees. The program was run for 5 millions generations with the TPm 2 uf $+\mathrm{G}$ substitution model. The first $10 \%$ of the interactions were discarded as burn-in.

\section{Results and Discussion}

The specimens grew abundantly on Allium cepa L. used as bait and later onto PYGs (figure 1a), with a great number of cells produced in one week (figures 1b, 1c).

The BLASTn query showed that these specimens belong to Pseudozyma aphidis (alignment in the Treebase, http://purl.org/ phylo/treebase/phylows/study/TB2:S21546). Our isolates of $P$. aphidis are well supported and clustered together with other isolates of the same species $(90 \%$ of bootstrap support with high values of posterior probability (0.98), as shown in figure 2. This species has a close phylogenetic affinity with $P$. rugulosa ( $80 \%$ of bootstrap support and 0.98 of posterior probability), as previously demonstrated (Chang et al. 2008).

The culture collection numbers of the isolates obtained in this study and their respective sequences deposited in GenBank database are shown in table 1.

Although $P$. aphidis has been already reported in Brazil (Costa 2006, Tristão et al. 2012, Parahym et al. 2013) and worldwide, this is the first report from a mangrove area in São Paulo State.

\section{Acknowledgements}

We are indebted to "Instituto Florestal" for the permission given to collect samples at PEIC. Also, we would like to thank FAPESP ("Fundação de Amparo à Pesquisa do Estado de São Paulo") for the financial support given to C.L.A. Pires-Zotarelli (process $n^{\circ}$ 2012/50222-7) and CNPq ("Conselho Nacional de Desenvolvimento Científico e Tecnológico”) is also acknowledged for the grant given to C.L.A. PiresZottarelli (process no $304411 / 2012-4$ ).

\section{Literature cited}

Bandoni, R.J. 1985. On an undescribed, pleomorphic hyphomycete from litter. Botanical Journal of the Linnean Society 91: 37-43.

Barros, F., Melo, M.M.R.F., Chiea, S.A.C., Kirizawa, M., Wanderley, M.G.L. \& Jung-Mendaçolli, S.L. 1991. Flora fanerogâmica da Ilha do Cardoso: caracterização geral da vegetação e listagem das espécies ocorrentes. Boletim do Instituto de Botânica 1: 1-184.

Boekhout, T. 1995. Pseudozyma Bandoni emend. Boekhout, a genus for yeast-like anamorphs of Ustilaginales. Journal of General and Applied Microbiology 41: 359-366.

Boekhout, T., Fonseca, A., Sampaio, J.P., Bandoni, R.J., Fell, J.W. \& Kwong-Chung. 2011. Discussion of teleomorphic and anamorphic basidiomycetous yeast. In: C.P. Kurtzman, J.W. Fell \& T. Boekhout (eds.). The yeast, a taxonomic study. Elsevier, Amsterdam, pp. 1339-1372.

Boettinger, C. \& Lang, D.T. 2012. Treebase: an R package for discovery, access and manipulation of online phylogenies. Methods in Ecology and Evolution 3: 1060-1066.

Buxdorf, K., Rahat, I. \& Levy, M. 2013a. Pseudozyma aphidis induces ethylene independent resistance in plants. Plant Signaling \& Behavior 8: e26273. 
Buxdorf, K., Rahat, I., Gafni, A. \& Levy, M. 2013 b. The epiphytic fungus Pseudozyma aphidis induces jasmonic acid and salicylic acid/nonexpressor of PR1-independent local and systemic resistance. Plant Physiology 161: 2014-2022.

Chamnanpa, T., Limtong, P., Srisuk, N. \& Limtong, S. 2013. Pseudozyma vetiver sp. nov., a novel anamorphic ustilaginomycetous yeast species isolated from the phylloplane in Thailand. Antonie van Leeuwenhoek 104: 637-644.

Chang, M.H., Kim, H.J., Jahng, K.Y. \& Hong, S.C. 2008. The isolation and characterization of Pseudozyma sp. JCC 207, a novel producer of squalene. Applied Microbiology and Biotechnology 78: 963-972.

Costa, M.S.F. 2006. Diversidade de leveduras do solo semiárido da Bahia, Brasil. Tese de Doutorado, Universidade Federal de Pernambuco, Recife.

Dimitrijević, A., Velicković, D., Bezbradica, D., Bihelović, F., Jankov, R. \& Milosavić, N. 2011. Production of lipase from Pseudozyma aphidis and determination of the activity and stability of the crude lipase preparation in polar organic solvents. Journal of the Serbian Chemical Society 76: 1081-1092.

Fan, L.L., Dong, Y.C., Fan, Y.F., Zhang, J. \& Chen, Q.H. 2014. Production and identification of mannosylerythritol lipid-A homologs from the ustilaginomycetous yeast Pseudozyma aphidis ZJUDM34. Carbohydrate Research 392: 1-6.

Fell, J.W., Statzell-Tallman, A., Scorzetti, G. \& Gutierrez, M.H. 2011. Five new species of yeasts from fresh water and marine habitats in the Florida Everglades. Antonie van Leeuwenhoek 99: 533-549.

Fischer, B. \& Brebeck, C. 1984. Zur Morphologie, Biologie und Systematik der Kahmpilze, der Monilia candida Hansen und des Soorerregers. G. Fischer Jena: 1-52.

Fuller, M.S. \& Jaworski, A. 1987. Zoosporic Fungi in teaching and research. Palfrey Contributions in Botany 3. Southeastern Publishing. Athens, Georgia.

Gadanho, M., Almeida, J.M.G.C.F. \& Sampaio, J.P. 2003. Assessment of yeast diversity in a marine environment in the south of Portugal by microsatelliteprimed PCR. Antonie van Leeuwenhoek 84: 217-227.

Gafni, A., Caldero, C.E., Harris, R., Buxdorf, K., Dafa-Berger, A., Zeilinger-Reichert, E. \& Levy, M. 2015. Biological control of the cucurbit powdery mildew pathogen Podosphaera xanthii by means of the epiphytic fungus Pseudozyma aphidis and parasitism as a mode of action. Frontier in Plant Science 6: 1-11.

Golubev, W., Sugita, T. \& Golubev, N. 2007. An ustilaginomycetous yeast, Pseudozyma graminicola sp. nov., isolated from the leaves of pasture plants. Mycoscience 48: 29-33.
Guindon, S. \& Gascuel, O. 2003. A Simple, fast, and accurate algorithm to estimate large phylogenies by Maximum Likelihood. Systematic Biology 52: 679-704.

Günther, M., Grumaz, C., Lorenz, S., Stevens, P., Lindemann, E., Hirth, T., Sohn, K., Zibek, S. \& Rupp, S. 2015. The transcriptomic profile of Pseudozyma aphidis during production of mannosylerythritol lipids. Applied Microbiology and Biotechnology 99: 1375-1388.

Han, S.M., Hyun, S.H., Lee, H.B., Lee, H.W., Kim, H.K. \& Lee, J.S. 2015. Isolation and Identification of Yeasts from Wild Flowers Collected around Jangseong Lake in Jeollanam-do, Republic of Korea, and Characterization of the Unrecorded Yeast Bullera coprosmaensis. Mycobiology 43: 266-271.

Henninger, W. \& Windisch, S. 1975. A new yeast of Sterigmatomyces, S. aphidis sp. n. Archive Microbiology 105: 49-50.

Herb, A., Sabou, M., Delhorme, J.B., Pessaux, P., Mutter, D., Candolfi, E. \& Letscher-Bru, V. 2015. Pseudozyma aphidis fungemia after abdominal surgery: First adult case. Medical Mycology 8: 37-39.

Hoog, G.S., Bowman, B. \& Graser, Y. 1998. Molecular phylogeny and taxonomy of medically important: Fungi. Medical Mycology 36: 52-56.

Index Fungorum. 2016. Index Fungorum. Available in http://www.indexfungorum.org/ (accessed in 07-XI-2016).

Joo, H., Choi, Y.G., Cho, S.Y., Choi, J.K., Lee, D.G., Kim, H.J., Jo, I., Park, Y.J. \& Lee, K.Y. 2015. Pseudozyma aphidis fungemia with invasive fungal pneumonia in a patient with acute myeloid leukaemia: case report and literature review. Mycoses: Diagnosis, Therapy and Prophylaxis of Fungal Diseases 59: 56-61.

Kazutaka, K. \& Daron, M. 2013. MAFFT Multiple Sequence Alignment Software Version 7: Improvements in Performance and Usability. Available in http://mafft. cbrc.jp/alignment/server (accessed in 10-VI-2016).

Kearse, M., Moir, R., Wilson, A.,Stones-Havas, S., Cheung, M., Sturrock, S., Buxton, S., Cooper, A., Markowitz, S., Duran, C., Thierer, T., Ashton, B., Meintjes P. \& Drummond A. 2012. Geneious Basic: an integrated and extendable desktop software platform for the organization and analysis of sequence data. Bioinformatics 28: 1647-1649.

Kutty, S.N. \& Philip, R. 2008. Marine yeasts - a review. Yeast 25: 465-483.

Limtong, S. \& Kaewwichian, R. 2015. The diversity of culturable yeasts in the phylloplane of rice in Thailand. Annals of Microbiology 65: 667-675.

Liou, G.Y., Wei, Y.H., Lin, S.J., Wen, C.Y. \& Lee, F.L. 2009 Pseudozyma pruni sp. nov., a novel ustilaginomycetous anamorphic fungus from flowers in Taiwan. International Journal of Systematic and Evolutionary Microbiology 59: 1813-1817. 
Lorenz, S., Günther, M., Grumaz, C., Rupp, S., Zibek, S. \& Sohn, K. 2014 Genome Sequence of the Basidiomycetous Fungus Pseudozyma aphidis DSM70725, an Efficient Producer of Biosurfactant Mannosylerythritol Lipids. Genome Announcements 2: e00053-14

Marano, A.V., Jesus, A.L., de Souza, J.I., Leãno, E.M., James, T.Y., Jerônimo, G.H., de Cock, A.W.A.W. \& Pires-Zottarelli, C.L.A. 2014. A new combination in Phytopythium: P. kandeliae (Oomycetes, Straminipila). Mycosphere 5: 510-522.

Mekha, N., Takashima, M., Boon-Long, J., Cho, O. \& Sugita, T. 2014. Three new basidiomycetous yeasts, Pseudozyma alboarmeniaca sp. nov., Pseudozyma crassa sp. nov. and Pseudozyma siamensis sp. nov. isolated from Thai patients. Microbiology and Immunology 58: 9-14.

Milanez, A.I. 1989. Fungos de águas continentais. In: O. Fidalgo, V.L. Bononi (coords.). Técnicas de coleta, preservação e herborização de material botânico. Série Documentos Instituto de Botânica, São Paulo, pp. 17-20.

Morita, T., Konishi, M., Fukuoka, T., Imura, T. \& Kitamoto, D. 2007. Physiological differences in the formation of the glycolipid biosurfactants, mannosylerythritol lipids, between Pseudozyma antarctica and Pseudozyma aphidis. Applied Microbiology and Biotechnology 74: 307-315.

Nasanit, R., Tangwong-o-Thai, A., Tantirungkij, M. \& Limtong, S. 2015. The assessment of epiphytic yeast diversity in sugarcane phyllosphere in Thailand by culture-independent method. Fungal Biology 119: 1145-1157.

Oliveira, J.V.C., Borges, T.A., dos Santos, R.A.C., Freitas, L.F.D., Rosa, C.A., Goldman, G.H. \& RiañoPachón, D.M. 2014. Pseudozyma brasiliensis sp. nov., a xylanolytic, ustilaginomycetous yeast species isolated from an insect pest of sugarcane roots. International Journal of Systematic and Evolutionary Microbiology 64: 2159-2168.

Orecchini, L.A., Olmos, E., Taverna, C.G., Murisengo, O.A., Szuzs, W., Vivot, W., Córdoba, S., BoscoBorgeat, M.E. \& Montanaro, P.C. 2015. First Case of fungemia due to Pseudozyma aphidis in a pediatric patient with osteosarcoma in Latin America. Journal of Clinical Microbiology 53: 3691-3694.

Parahym, A.M.R.C., da Silva, C.M., Domingos, I.F., Gonçalves, S.S., Rodrigues, M.M., de Morais, V.L.L. \& Neves, R.P. 2013. Pulmonary infection due to Pseudozyma aphidis in a patient with burkitt lymphoma: first case report. Diagnostic Microbiology and Infectious Disease 75: 104-106.
Piatek, M., Lutz, M. \& Yorou, N.S. 2015. A molecular phylogenetic framework for Anthracocystis (Ustilaginales), including five new combinations (inter alia for the asexual Pseudozyma flocculosa), and description of Anthracocystis grodzinskae sp. nov. Mycologycal Progress 14: 1-15.

Posada, D. 2008. jModelTest: Phylogenetic model averaging. Molecular Biology Evolution 25: 1253-1256.

Prakash, A., Wankhede, S., Singh, P.K., Agarwal, K., Kathuria, S., Sengupta, S., Barman, P., Meis, J.F. \& Chowdhary, A. 2014. First neonatal case of fungaemia due to Pseudozyma aphidis and a global literature review. Mycoses 57: 64-68.

Robideau, G.P., de Cock, A.W.A.M., Coffey, M.D., Voglmayr, H., Brouwer, H., Bala, K., Chitty, D.W., Désaulniers, N., Eggertson, Q.A., Gachon, C.M.M., Hu, C.H., Küpper, F.C., Rintoul, T.L., Sarhan, E., Verstappen, E.C.P., Zhang, Y., Bonants, P.J.M., Ristaino, J.B. \& Lévesque, A.C. 2011. DNA barcoding of oomycetes with cytochrome c oxidase subunit I and internal transcribed spacer. Molecular Ecology Resources 11: 1002-1011.

Ronquist, F., Huelsenbeck, J.P. 2003. MrBayes 3: Bayesian phylogenetic inference under mixed models. Bioinformatics 19: 1572-1574.

Sparrow Jr., F.K. 1960. Aquatic Phycomycetes. Ambassador Books (2th revised edition), Toronto, pp. 1187

Statzell-Tallman, A., Scorzetti, G. \& Fell, J.W. 2010. Candida spencermartinsiae sp. nov., Candida taylorii sp. nov. and Pseudozyma abaconensis sp. nov., novel yeasts from mangrove and coral reef ecosystems. International Journal of Systematic and Evolutionary Microbiology 60: 1978-1984.

Sugita, T., Takashima, M., Poonwan, N., Mekha, N., Malaithao, K., Thungmuthasawat, B., Prasarn, S., Luangsook, P. \& Kudo, T. 2003. The First Isolation of Ustilaginomycetous Anamorphic Yeasts, Pseudozyma Species, from Patients' Blood and a Description of Two New Species: P. parantarctica and P. thailandica. Microbiology and Immunology 47: 183-190.

Tantirungkij, M., Nasanit, R. \& Limtong, S. 2015. Assessment of endophytic yeast diversity in rice leaves by a culture-independent approach. Antonie van Leeuwenhoek 108: 633-647.

Tristão, G.B., Malta, C.M., Borges, A.K.P., de Morais, P.B., da Silva, J.F.M. \& Pimenta, R.S. 2012. Leveduras associadas a frutos de abacaxi (Ananas comosus) e sua utilização como agente de controle biológico. Engenharia Ambiental - Espírito Santo do Pinhal 9: 85-93. 
Vogel, C., Rogerson, A., Scatz, S., Laubach, H., Tallman, A. \& Fell, J.W. 2007. Prevalence of yeast in beach sand at three bathing beaches in South Florida. Water Research 41: 1915-1930.

Wang, Q.M., Jia, J.H. \& Bai, F.Y. 2006. Pseudozyma hubeiensis sp. nov. and Pseudozyma shanxiensis sp. nov., novel ustilaginomycetous anamorphic yeast species from plant leaves. International Journal of Systematic and Evolutionary Microbiology 56: 289-293.

Wang, Q.M., Begerow, D., Groenewald, M., Liu, X.Z., Theelen, B., Bai, F.Y. \& Boekhout, T. 2015. Multigene phylogeny and taxonomic revision of yeasts and related fungi in the Ustilaginomycotina. Studies in Mycology 81: 55-83.
Wei, Y.H., Lee, F.L., Hsu, W.H., Chen, S.R., Chen, C.C., Wen, C.Y., Lin, S.J., Chu, W.S., Yuan, G.F. \& Liou, G.Y. 2005. Pseudozyma antarctica in Taiwan: a description based on morphological, physiological and molecular characteristics. Botanical Bulletin of Academia Sinica 46: 223-229.

White, T.J., Bruns, T., Lee, S. \& Taylor, J. 1990. Amplification and direct sequencing of fungal ribosomal RNA genes for phylogenetics. In: M.A. Innis, D.H. Gelfand, J.J. Sninsky \& T.J. White (eds.). PCR Protocols: A Guide to Methods and Applications. San Diego, CA: Academic Press, pp. 315-324. 